Article

\title{
Anti-Inflammatory Activity and Mechanism of Cryptochlorogenic Acid from Ageratina adenophora
}

\author{
Xiaoping Ma ${ }^{1,2,+}$, Samuel Kumi Okyere ${ }^{1,2,+} \mathbb{D}$, Liwen $\mathrm{Hu}^{1,2}$, Juan Wen ${ }^{1,2}$, Zhihua Ren ${ }^{1,2}$, Junliang Deng ${ }^{1,2}$ \\ and Yanchun $\mathrm{Hu}^{1,2, *}$
}

check for updates

Citation: Ma, X.; Okyere, S.K.; Hu, L.; Wen, J.; Ren, Z.; Deng, J.; Hu, Y. Anti-Inflammatory Activity and Mechanism of Cryptochlorogenic Acid from Ageratina adenophora. Nutrients 2022, 14, 439. https:// doi.org/10.3390/nu14030439

Academic Editors: Daniela Rigano and Paola Bontempo

Received: 19 December 2021

Accepted: 17 January 2022

Published: 19 January 2022

Publisher's Note: MDPI stays neutral with regard to jurisdictional claims in published maps and institutional affiliations.

Copyright: (C) 2022 by the authors. Licensee MDPI, Basel, Switzerland. This article is an open access article distributed under the terms and conditions of the Creative Commons Attribution (CC BY) license (https:// creativecommons.org/licenses/by/ $4.0 /)$.
1 Key Laboratory of Animal Diseases and Environmental Hazards of Sichuan Province, College of Veterinary Medicine, Sichuan Agricultural University, Chengdu 611130, China; mxp886@sicau.edu.cn (X.M.); samuel20okyere@gmail.com (S.K.O.); huliwen197@163.com (L.H.); juanwen881010@163.com (J.W.); zhihua_ren@126.com (Z.R.); dengi1213@126.com (J.D.)

2 Key Laboratory of Animal Disease and Human Health of Sichuan Province, Sichuan Agricultural University, Chengdu 611130, China

* Correspondence: yanchunhu@sicau.edu.cn; Tel.: +86-2886291162

+ These authors contributed equally to this work.

\begin{abstract}
Ageratina adenophora is an invasive plant known for its toxicity to livestock. Current research on this plant has shifted from toxicity prevention to the beneficial utilization of plant resources. This study was performed to investigate the effects and mechanisms of cryptochlorogenic acid (CCGA) isolated from Ageratina adenophora on the inflammatory responses induced by lipopolysaccharide (LPS) in RAW264.7 cells. RAW264.7 cells were pretreated with CCGA (200, 100, and $50 \mu \mathrm{g} / \mathrm{mL})$ and subsequently stimulated with LPS $(1 \mu \mathrm{g} / \mathrm{mL})$ for $16 \mathrm{~h}$. The cytotoxicity of CCGA was tested using the Cell Counting Kit (CCK8). The mechanism of action of CCGA in attenuating inflammation was also identified using enzyme-linked immunosorbent assay (ELISA), quantitative reverse transcription-polymerase chain reaction, and Western blot. The results showed that CCGA had a maximal safe concentration of $200 \mathrm{mg} / \mathrm{mL}$. Moreover, CCGA reduced the level of nitric oxide (NO) and iNOS in LPS-induced RAW264.7 cells $(p<0.01)$. In addition, CCGA reduced the levels of proinflammatory cytokines (TNF- $\alpha$, IL-1 $\beta$, IL-6, and IL-8) and cyclooxygenase-2 (COX-2) in LPS-induced RAW264.7 cells at both the mRNA and protein levels $(p<0.01)$. CCGA prevented the activation of nuclear factor-kappa B (NF-kB) in LPS-induced RAW264.7 cells via the inhibition of IKK and IkB phosphorylation and the degradation of I $\kappa$ B proteins $(p<0.01)$. This finding indicated that CCGA isolated from A. adenophora may be a potential candidate for the treatment of inflammation-related diseases.
\end{abstract}

Keywords: Ageratina adenophora; cryptochlorogenic acid; anti-inflammatory; nuclear factor-kappa B pathway

\section{Introduction}

The chief tool used by most organisms against infection is inducing inflammatory responses [1]. However, elevated levels of inflammatory cytokines in the body circulation or in local inflammatory sites result in severe diseases [2-4]. Chronic inflammation is linked with various diseases, such as diabetes, depression, and cancer [5-13]. Among the inflammatory inducing agents, lipopolysaccharide (LPS) is reported to enhance the production of pro-inflammatory cytokines in macrophages, fibroblasts, and monocytes [14]. Furthermore, it has been reported that LPS-induced inflammatory reactions can occur via the NF- $\mathrm{B}$ signaling pathway [15]. TNF- $\alpha$ cytokine actively takes part in systemic inflammation as well as immune cell regulation [16]. IL-1 $\beta$ is known for activating the plasmalemmal IL-1R1 receptor in various types of cells $[17,18]$. IL-6 is involved in numerous cellular activities, including cell proliferation, differentiation, and apoptosis [19]. IL-8 is a pro-inflammatory cytokine that is linked to tumor growth and progression [20]. Cyclooxygenase (COX) is an oxidoreductase enzyme noted for the conversion of arachidonic acid to prostaglandins, 
thereby initiating inflammatory reactions [21]. COX-2 is associated with PGE2 synthesis in numerous examples of inflammation [22].

Nitrite oxide (NO) is an inflammatory mediator of the nitric oxide synthase (NOS) family [23]. Three types of NOSs have been identified, namely, inducible NOS (iNOS), neuronal NOS (nNOS), and endothelial NOS (eNOS) [24]. Both nNOS and eNOS are constitutive NOSs, whereas iNOS is activated by cytokines to yield NO [25]. An increase in $\mathrm{NO}$ concentration in cells causes cytotoxicity and induces various inflammatory disorders [26,27].

Inflammation is linked with the NF- $\mathrm{KB}$ pathway. NF- $\mathrm{kB}$ is a nuclear transcriptional factor that is linked to both pro- and anti-inflammatory activities [28]. In dormant cells, the NF- $k B$ dimers are joined by inhibitory molecules, such as I $k B$, to keep them stable in the cytoplasm. LPS activates IKK to initiate the phosphorylation of IKB in cells, which causes the degradation of $\mathrm{I} \kappa \mathrm{B} \alpha$ protein and the activation of NF- $\mathrm{kB}$ translocation into the nucleus to bind target DNAs [29].

Inflammation is one of the key drivers of pathogenesis in many diseases; therefore, over the past years, numerous studies have identified and isolated many anti-inflammatory compounds from natural products, especially from plant sources, because they produce fewer side effects compared with commercial drugs. Among these compounds from natural products, polyphenolic compounds in plants are the most widely known to possess anti-inflammation activities [30], whereas phenolic acids are the most abundant among plant polyphenolic compounds. They have been isolated from different plant parts, such as the leaves and seeds of vegetables and the skins of fruits [31]. Among the phenolic acid group, chlorogenic acid is the most well-known and abundant compound known to possess beneficial biological properties, such as anticancer, anti-inflammatory, antioxidant, antimicrobial, and antiviral effects [32-35]. Cryptochlorogenic acid (CCGA) (Figure 1), a distinct isomer of chlorogenic acid with similar structural features, has also demonstrated potential anti-inflammatory activities in previous studies [36,37].

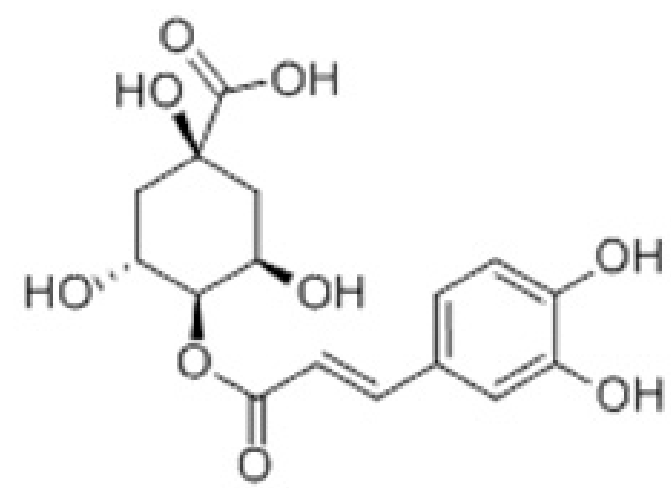

Figure 1. Chemical structure of cryptochlorogenic acid (CCGA).

Ageratina adenophora (Spreng.) R. M. King et H. Rob. is one of the most harmful invasive plants in China [38-41]. It has strong environmental adaptability and breeding ability, which can cause serious ecological disasters and affect the growth of the animal husbandry industry [42]. However, at present, the focus of research on A. adenophora has shifted from toxicity prevention to the biological utilization of the plant resource [43-45]; thus, researchers have identified several secondary metabolites with pharmacological properties, such as antibacterial, antitumor, anti-obesity, anticancer, and anti-inflammation effects, in this plant resource [46]. Cryptochlorogenic acid (CCA) is one of the major polyphenolic bioactive compounds isolated from A. adenophora [46]; however, its effects and mechanism in inflammation are still unknown. Therefore, this work was performed to explore the anti-inflammatory activity of CCGA isolated from A. adenophora in order to discover the pharmacological effects of CCGA as well as its molecular pathway. 


\section{Materials and Methods}

\subsection{Plant Sample, Chemicals, and Reagents}

The collection, location, and identification of Ageratina adenophora for this study were reported in a study by Okyere et al. (2022). Cells: The RAW264.7 murine cell line was purchased from the Wuhan China Typical Culture Preservation Center (Wuhan, China), which offered Short Tandem Repeat (STR) analysis to confirm the authenticity of all cell lines. Lipopolysaccharides (LPS) were derived from Escherichia coli O111:4. High-glucose DMEM and CCK-8 were obtained from HyClone. The imported test kit for fetal bovine serum (GIBCO), the nitric oxide (NO) box, and ELISA kits for TNF- $\alpha$, IL-1 $\beta$, IL-6, IL-8, IL-10, and COX-2 were purchased from Nanjing Jiancheng Company Ltd., Nanjing, China. The total RNA extraction kit and fluorescent quantitative PCR kit were obtained from the Beyotime Institute of Biotechnology (Beijing, China). Secondary antibodies were bought from the Beyotime Institute of Biotechnology (Beijing, China). All experiments were undertaken following the approved guidelines and experimental protocols by the Animal Care and Use Committee of Sichuan Agricultural University, China (no. 2019603005).

\subsection{Extraction of CCGA}

Preparation of Aqueous Extract from Ageratina adenophora

Fifty grams (50) of milled leaves was mixed in $100 \mathrm{~mL}$ of water and soaked for $12 \mathrm{~h}$. The upper layer containing the organic solvent was collected and filtered by suction. After rotating evaporation at $105 \mathrm{kpa}$ and $45^{\circ} \mathrm{C}$, the upper layer containing the organic solvent was dissolved in $1000 \mathrm{~mL}$ of extraction solution to begin the extraction process. The liquid ratio used for the extraction was methanol: ethyl acetate: water $=2: 5: 8(v / v / v)$. After that, the lower part of the aqueous phase was collected and evaporated at $75{ }^{\circ} \mathrm{C}$ to obtain a yellowish-brown aqueous extract.

\subsection{Separation of Cryptochlorogenic Acid by Macroporous Resin \\ 2.3.1. Macroporous Resin Pretreatment}

HPD100 macroporous resin was soaked with 95\% ethanol for $24 \mathrm{~h}$. After full swelling, it was washed with ethanol and an appropriate amount of water until the effluent had no white turbidity. Afterward, it was soaked in distilled water until there was no smell of alcohol.

\subsubsection{Sample Loading and Elution System}

The aqueous extract was dissolved in $95 \%$ ethanol, and the ratio of ethanol volume to extract was 10:1 (v/w). Using 5\%,15\%,65\%, and 95\% as eluent, the elution amount was 6 times of column volume. The eluent was then collected from below the column. The collected eluent and cryptochlorogenic acid standard were developed using the mixture of methanol and ethyl acetate in a ratio of 95:5 (v/v) as the layer-developing agent, and $2 \%$ ferric chloride solution was used as the color developing agent. The samples were collected according to the color-developing points for silica gel column chromatography.

\subsection{Purification of Cryptochlorogenic Acid by Silica Gel Column Chromatography}

Step 2.3 was repeated 5-6 times, and the eluate containing chlorogenic acid was combined for the sample of silica gel column chromatography. The silica gel powder was mixed with ethyl acetate and poured into a clean silica gel column. Twice the column volume of ethyl acetate was used as the eluent to stabilize the column, and the bubblefree column was used as the separation column. Samples were dissolved in ethyl acetate in a ratio of $4: 1$, and $20 \mathrm{~mL}$ of the sample was taken and slowly added to the silica gel column of the above cabinet. After loading, the valve was opened to allow the sample to enter the silica gel column. Using an ethyl acetate to methanol ratio of 98:2 $(v / v)$ and a methanol to ethyl acetate ratio of 95:5 $(v / v)$ as eluent, the elution amounts were 3 times the column volume and 6 times the column volume, respectively. The eluent containing 
cryptochlorogenic acid was collected and combined by thin layer chromatography for secondary column passing.

\subsection{Identification of Monomer Purity by Ultra High Performance Liquid Chromatography}

\subsubsection{Chromatographic Conditions}

In this analysis, an Agilent 1290 ultra-high liquid chromatograph (chromatographic column: XDB-C18 $(2.1 \times 100 \mathrm{~mm}, 1.8 \mu \mathrm{m})$ was used to analyze chlorogenic acid using water (A) and methanol (B) as mobile phases, methanol- $0.1 \%$ formic acid solution (30:70), a flow rate of $0.3 \mathrm{~mL} / \mathrm{min}$, a detection wavelength of $325 \mathrm{~nm}$, and a column temperature of $28^{\circ} \mathrm{C}$. The sample injection volume was $1 \mu \mathrm{L}$, and the peak time was between $1.28 \mathrm{~min}$ and $12 \mathrm{~h}$.

\subsubsection{Making the Standard Curve}

The standard chlorogenic acid of $0.7 \mathrm{mg}$ was accurately weighed and poured into a $3.5 \mathrm{~mL}$ volumetric flask; after that, it was dissolved in methanol, ultrasonic, and cooled. After cooling, $0.2 \mathrm{mg} / \mathrm{mL}$ concentration solution was prepared using methanol. The prepared solution was then diluted to different concentrations $(0.01,0.05,0.10,0.15$, and $0.20 \mathrm{mg} / \mathrm{mL}$ ), and $1 \mu \mathrm{L}$ of the above standard solution and sample in sequence were loaded. The peak area was determined by ultra-high performance liquid chromatography (UHPLC) according to the chromatographic conditions in 2.5.1. The standard curve was drawn with the peak area as the ordinate and the standard concentration as the abscissa.

\subsubsection{Determination of Cryptochlorogenic Acid in Ageratina adenophora}

An amount of $0.7 \mathrm{mg}$ of the extract monomer was weighed and fixed into $3.5 \mathrm{~mL}$ of chromatographic methanol. UHPLC determination was conducted according to the chromatographic conditions in 2.5.1, and the content of cryptochlorogenic acid in the extracted monomer was calculated according to the standard curve.

\subsection{Cell Viability Using CCK8 Method}

The cytotoxicity of CCGA was investigated using the CCK-8 (cell counting kit8) assay. RAW264.7 cells in the logarithmic growth phase were used for this experiment. After counting with a cell counting plate, $100 \mu \mathrm{L}$ of cell suspension with $5 \times 10^{4}$ cells was seeded on a 96 well plate and cultured at $37^{\circ} \mathrm{C}$ and $5 \% \mathrm{CO}_{2}$ for $24 \mathrm{~h}$. After $24 \mathrm{~h}$ of culture at $37^{\circ} \mathrm{C}$ and $5 \% \mathrm{CO}_{2}, \mathrm{CCGA}$ was released at $400,200,100$, and $50 \mu \mathrm{g} / \mathrm{mL}$ concentrations for $24 \mathrm{~h}$ in DMEM. DMEM was added to the 96-well plate, blank group, and LPS group. After $4 \mathrm{~h}$ of continuous culture, $100 \mu \mathrm{L}$ of cells without stimulation DMEM was added to the blank control group. The LPS group and experimental group were induced with LPS solution at a concentration of $1 \mu \mathrm{g} / \mathrm{mL}$. for $16 \mathrm{~h}$. After the replacement of fresh DMEM, $10 \mu \mathrm{L}$ of CCK-8 reagent was added to each well and incubated at $37^{\circ} \mathrm{C}$ for $4 \mathrm{~h}$. Each group was set with 3 multiple wells and blank wells (with DMEM and CCK-8 solution, without cells). The absorbance was measured at a $450 \mathrm{~nm}$ wavelength. The data are represented as means \pm standard deviation. Cell viability was calculated as:

Cell viability $(\%)=($ treatment well OD-blank well OD) $/($ blank group OD-blank well OD $) \times 100 \%$

From the experimental results of CCK-8, the concentration groups of 200, 100, and $50 \mu \mathrm{g} / \mathrm{mL}$ CCGA were selected for further experiments. Therefore, we designed an experimental study of a blank control group, LPS group, and experimental group with concentrations of 200,100, and $50 \mu \mathrm{g} / \mathrm{mL}$. Each group was provided with 3 multiple wells. The experiment was performed in triplicate.

\subsection{Measurement of Nitric Oxide in RAW264.7 Cells}

Nitric oxide levels were measured following the procedure by Ying et al. [25]. RAW264.7 cells were pretreated with CCGA at 50-200 $\mu \mathrm{g} / \mathrm{mL}$ for $24 \mathrm{~h}$; after that, cells were stimulated with LPS $(1 \mu \mathrm{g} / \mathrm{mL})$ for $16 \mathrm{~h}$. Then, Griess reagent was used to estimate the NO production in the medium. For the blank groups, we used a sterile culture medium. The quantity 
of nitrite in the samples was measured by using the sodium nitrite standard curve as a reference point.

2.8. Enzyme-Linked Immunosorbent Assay (ELISA) for Detecting TNF- $\alpha, I L-1 \beta, I L-6, I L-8, I N O S$, COX-2, and IL-10 Production

ELISA assay for detecting TNF- $\alpha$, IL-1 $\beta$, IL-6, IL-8, IL-10, iNOS, and COX-2 production were pretreated with CCGA for $24 \mathrm{~h}$ and then induced with LPS (100 ng/mL) for $16 \mathrm{~h}$. The culture supernatant was estimated using commercially available ELISA kits. All procedures were accomplished by following the manufactures' instructions. The samples were analyzed in triplicate.

2.9. RNA Extraction and Real Time RT-PCR Analysis for Detecting TNF- $\alpha, I L-1 \beta, I L-6, I L-8$, IL-10, COX-2, and INOS Production

RAW264.7 cells were treated with different concentrations of CCGA for $24 \mathrm{~h}$ and stimulated with LPS. After $16 \mathrm{~h}$, the supernatant was collected as the sample to be tested. Cells were blown with $1 \mathrm{~mL}$ Trizol and collected at $-80{ }^{\circ} \mathrm{C}$ for RNA extraction. Afterward, RNA was extracted following the kit's instructions. The qRT-PCR was performed with $\beta$-actin as the control. The primers used are presented in Table 1 . The relative expression of the genes was deduced by the $2^{-\Delta \Delta}$ CT method, where, $\Delta \mathrm{CT}=\mathrm{CT}$ target gene-CT internal reference gene, $\Delta \Delta \mathrm{Ct}=\Delta \mathrm{CT}$ treated samples $-\Delta \mathrm{CT}$ control sample, and multiple change $=2^{-\Delta \Delta} \mathrm{C}$.

Table 1. Primers used for qRT-PCR.

\begin{tabular}{|c|c|c|}
\hline Genes & Primer Sequence $\left(5^{\prime} \rightarrow 3^{\prime}\right)$ & References \\
\hline \multirow{2}{*}{ TNF- $\alpha$} & F- AGCACAGAAAGCATGATCCG & \multirow{2}{*}{ [10] } \\
\hline & R-ATGAGAGGGAGGCCATT & \\
\hline \multirow{2}{*}{$\mathrm{IL}-1 \beta$} & F- GTTCCCCAACTGGTACATCA & \multirow{2}{*}{ [11] } \\
\hline & R- CCATACTTTAGGAAGACACGG & \\
\hline \multirow{2}{*}{ IL-6 } & F- CTTCTTGGGACTGATGCTGGT G & \multirow{2}{*}{ [12] } \\
\hline & R- CGCTGGCTTTGTCTTTCTTGTTA & \\
\hline \multirow{2}{*}{ IL-8 } & F- CAAGGCTGGTCCATGCTCC & \multirow{2}{*}{ [11] } \\
\hline & R- TGCTATCACTTCCTTTCTGTTG & \\
\hline \multirow{2}{*}{ IL-10 } & F- GCTCTTACTGACTGGCATGAG & \multirow{2}{*}{ [13] } \\
\hline & R- CGCAGCTCTAGGAGCATGTG & \\
\hline \multirow{2}{*}{ INOS } & F- TCCTACACCACACCAAAC & \multirow{2}{*}{ [10] } \\
\hline & R- CTCCAATCTCTGCСTATCC & \\
\hline \multirow{2}{*}{$\operatorname{cox}$} & F- TGCTGTACAAGCAGTGGCAA & \multirow{2}{*}{ [10] } \\
\hline & R- GCAGCCATTTCCTTCTCTCC & \\
\hline \multirow{2}{*}{$\beta$-actin } & F- CGGTTGGCCTTAGGGTTCAGGGGGG & \multirow{2}{*}{ [12] } \\
\hline & R- GTGGGCCGCTCTAGGCACCA & \\
\hline
\end{tabular}

F, forward; $\mathrm{R}$, reverse.

\subsection{Transient Transfection and Luciferase Activity Assay}

The transient transfection and luciferase activity assay was carried out following the methods and procedures of Ying et al. [25].

\subsection{Western Blot Analysis}

Using a scraper, cells were collected after thorough washing in ice-cold phosphatebuffered saline (PBS); after that, a protein extraction kit (Beyotime Institute of Biotechnology, Jiangsu, China) was used to extract the cytoplasmic proteins. The protein was resolved using SDS-PAGE and transferred to PVDF membranes. The membranes were incubated with blocking buffer $(5 \%(w / v)$ skimmed milk powder in 1 TBS containing $0.1 \%$ Tween-20 for $1 \mathrm{~h}$, then incubated overnight at $4{ }^{\circ} \mathrm{C}$ with a primary antibody (Santa Cruz Biotechnology, Santa Cruz, CA, USA). Membranes were incubated for $1 \mathrm{~h}$ at room temperature with HRP-linked secondary antibodies after the membrane was washed. Then, the membranes were washed again and detected using an enhanced chemiluminescence (ECL) kit and exposed to X-ray films (Kodak, Shanghai, China). 


\subsection{Statistical Analysis}

Statistical analyses were performed with SPSS software, version 20.0 (SPSS, Inc., Chicago, IL, USA). All data are presented as means \pm SD. One-way analysis of variance (ANOVA) followed by Tukey's post hoc multiple comparison test was used and $p<0.01$ was considered statistically significant.

\section{Results}

\subsection{Detection of Cryptochlorogenic Acid by Thin Layer Chromatography}

The results of the thin layer chromatography (TCL) are shown in Figure 2. The chromogenic points of the extracted monomers $C$ and D in the thin layer chromatography are the same as those of $\mathrm{A}$ and $\mathrm{B}$. Therefore, it was preliminarily inferred that the extracted monomers were cryptochlorogenic acid, and eluent with the same retention factors (RFs) was collected.

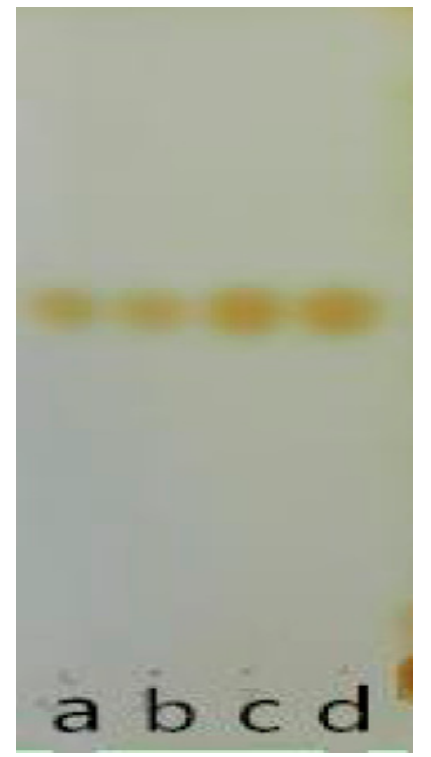

Figure 2. The results of TCL ( $\mathrm{a}$ and $\mathrm{b}$ are standard substances; $\mathrm{c}$ and $\mathrm{d}$ are extractive monomers).

3.2. Determination of the Purity of Cryptochlorogenic Acid by Ultra High Performance Liquid Chromatography

\subsubsection{Standard Curve of Cryptochlorogenic Acid}

As shown in Figure 3, according to UHPLC, the peak area of cryptochlorogenic acid standard was represented at the ordinate and the differential concentrations were represented at the abscissa. The graph showed the standard curve of cryptochlorogenic acid as $y=33039 x+94.402$, where $R^{2}=0.9995$, indicating that there was a good linear relationship between cryptochlorogenic acid standard and its concentration.

\subsubsection{Determination of Cryptochlorogenic Acid in Ageratina adenophora}

The UHPLC determination results of the cryptochlorogenic acid standard and cryptochlorogenic acid extracted from $A$. adenophora at $325 \mathrm{~nm}$ are shown in Figure 4 . The retention time of the cryptochlorogenic acid standard is $1.276 \mathrm{~min}$, and the retention time of monomer extracted from $A$. adenophora was $1.275 \mathrm{~min}$. It can be inferred that the monomer extracted from $A$. adenophora was cryptochlorogenic acid. In addition, the peak area of cryptochlorogenic acid extracted from $A$. adenophora in Figure 2 was 6324.19 , i.e., $\mathrm{y}=6324.19$; the concentration of cryptochlorogenic acid after dissolution was $0.189 \mathrm{mg} / \mathrm{mL}$; and the specific chlorogenic acid mass was $0.66 \mathrm{mg}$. It was calculated that the purity of cryptochlorogenic acid extracted from $A$. adenophora was $94.3 \%$. Therefore, we concluded that the amount of CCGA in $0.7 \mathrm{mg}$ extract was $0.6 \mathrm{mg}$ and the purity was $94.3 \%$. 


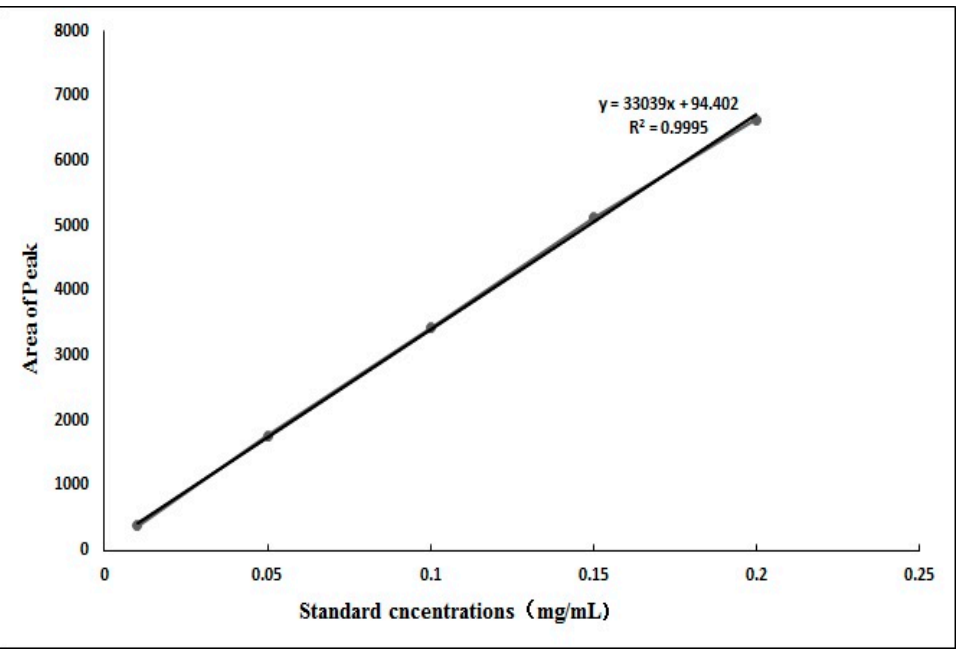

Figure 3. Standard linear regression curve.

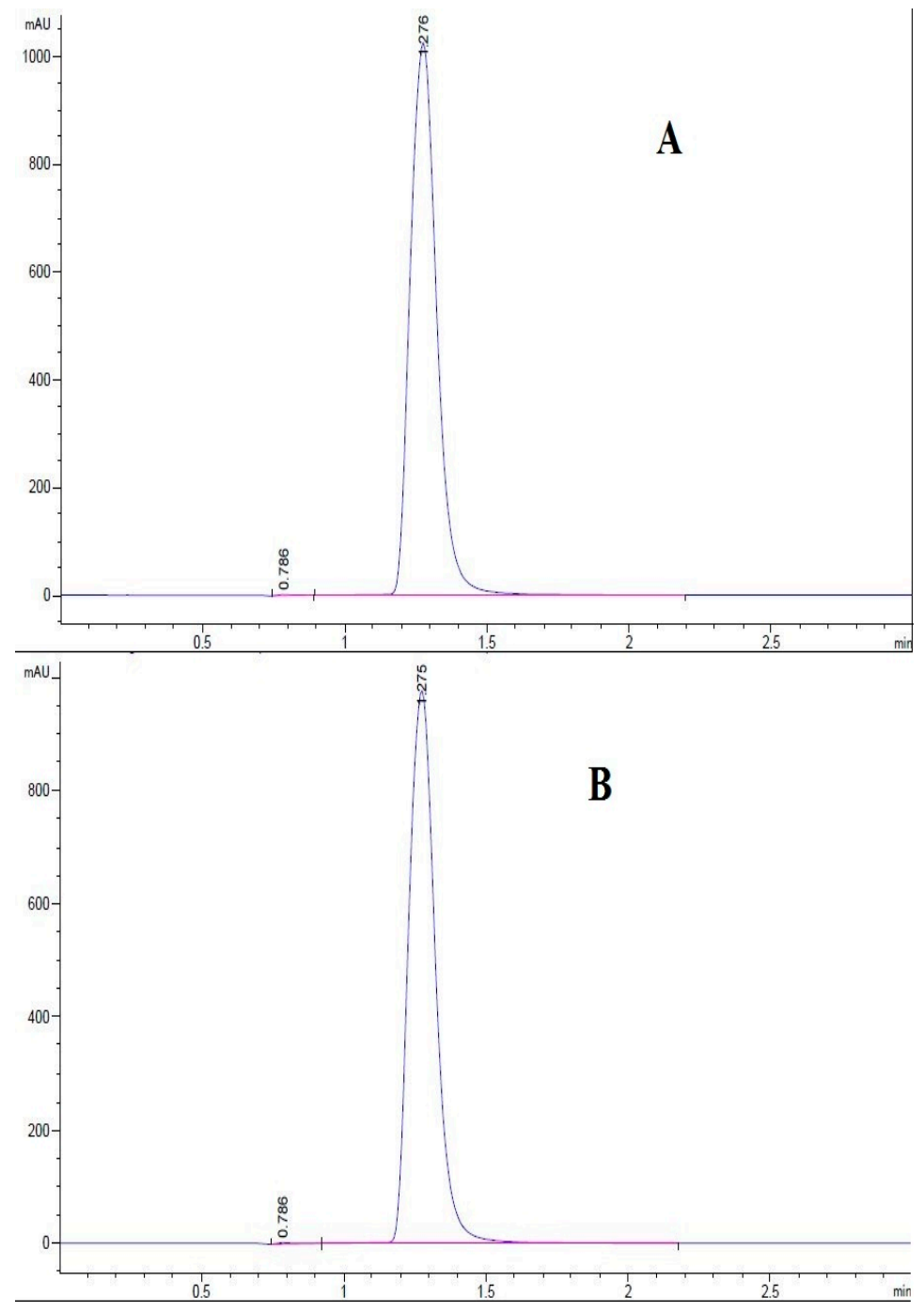

Figure 4. Determination of CCGA standard and extraction of CCGA from A. adenophora by UHPLC (A): Standard (0.2 mg/mL). (B): CCGA in A. adenophora. 


\subsection{Effects of CCGA on Cell Morphology and Cytotoxicity}

The experimental results (Figure 5A) showed that after CCGA treatment and LPS induction, the cells in the blank control, $200 \mu \mathrm{g} / \mathrm{mL}, 100 \mu \mathrm{g} / \mathrm{mL}$, and $50 \mu \mathrm{g} / \mathrm{mL}$ groups were smooth in appearance without pseudopodia, and some cells were compact in distribution and aggregated; however, the cells in the LPS and $400 \mu \mathrm{g} / \mathrm{mL}$ group were elongated with pseudopodia, and most of them were spindle-shaped.

A

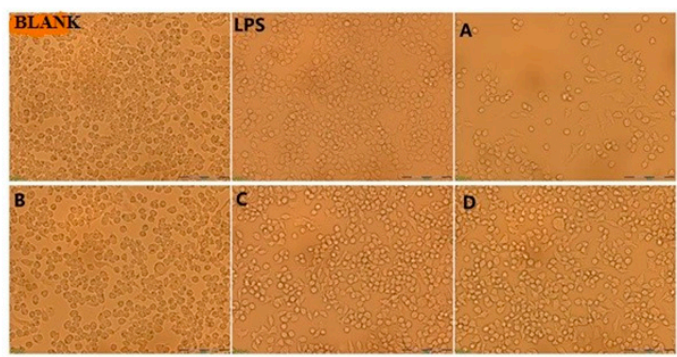

B

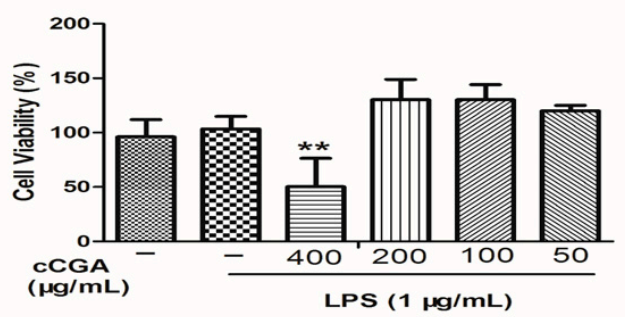

Figure 5. Cell morphology and viability after treatment with different concentrations of CCGA (BLANK: No LPS and CCGA treatments, LPS: Treatment with only LPS; A: $400 \mu \mathrm{g} / \mathrm{mL}$ CCGA $+1 \mu \mathrm{g} / \mathrm{mL}$ LPS; B: $200 \mu \mathrm{g} / \mathrm{mL}$ CCGA $+1 \mu \mathrm{g} / \mathrm{mL}$ LPS; C: $100 \mu \mathrm{g} / \mathrm{mL}$ CCGA $+1 \mu \mathrm{g} / \mathrm{mL}$ LPS; D: $50 \mu \mathrm{g} / \mathrm{mL}$ CCGA + $1 \mu \mathrm{g} / \mathrm{mL}$ LPS). (A) Photograph of viable cells after treatment with concentrations of CCGA (BLANK: No LPS and CCGA; LPS: Treatment with only LPS; A: $400 \mu \mathrm{g} / \mathrm{mL}$ CCGA + $1 \mu \mathrm{g} / \mathrm{mL}$ LPS; B: $200 \mu \mathrm{g} / \mathrm{mL}$ CCGA + $1 \mu \mathrm{g} / \mathrm{mL}$ LPS; C: $100 \mu \mathrm{g} / \mathrm{mL}$ CCGA + $1 \mu \mathrm{g} / \mathrm{mL}$ LPS; $\mathrm{D}: 50 \mu \mathrm{g} / \mathrm{mL}$ CCGA $+1 \mu \mathrm{g} / \mathrm{mL}$ LPS). (B) Viable cell count after treatment with concentrations of CCGA (A: $400 \mu \mathrm{g} / \mathrm{mL}$; B: $200 \mu \mathrm{g} / \mathrm{mL}$; C: $100 \mu \mathrm{g} / \mathrm{mL}$; D: $50 \mu \mathrm{g} / \mathrm{mL}$ ) Notes, ${ }^{* *} p<0.01 \mathrm{vs}$. LPS, $n=9$ (mean \pm standard deviation).

Furthermore, we observed that after $16 \mathrm{~h}$, cells treated with CCGA at a concentration of $400 \mu \mathrm{g} / \mathrm{mL}$ were significantly lower than that of the LPS group (Figure $5 \mathrm{~B}, p<0.01$ ), with a survival rate lower than $50 \%$. Therefore, we concluded that CCGA at a concentration of $400 \mu \mathrm{g} / \mathrm{mL}$ was toxic to RAW264.7 cells. However, the 200, 100, and $50 \mu \mathrm{g} / \mathrm{mL}$ CCGA concentrations and the LPS groups had cell viability above $100 \%$. Hence, we concluded that $1 \mu \mathrm{g} / \mathrm{mL}$ LPS and CCGA at concentrations of 200, 100, and $50 \mu \mathrm{g} / \mathrm{mL}$ did not show any obvious toxicity to RAW264.7 cells, and the maximum safe concentration of CCGA was $200 \mu \mathrm{g} / \mathrm{mL}$. Therefore, CCGA concentrations of 200,100, and $50 \mu \mathrm{g} / \mathrm{mL}$ were selected for subsequent tests.

\subsection{Effect of CCGA on LPS-Induced Nitric Oxide (NO) and iNOS Production}

In this study, we observed that CCGA could reduce the production of NO and the expression of iNOS in LPS-induced RAW264.7 cells compared with the LPS group (Figure $6 \mathrm{~A}-\mathrm{C}, p<0.01$ ).

3.5. The Regulatory Effect of CCGA from A. adenophora on Inflammation Related Cytokines in LPS-Induced RAW264.7 Cells

In this study, the mRNA and protein levels of pro-inflammatory cytokines (TNF- $\alpha$, IL-1 $\beta$, IL-6, and IL-8) were elevated in the LPS group compared with the blank control group (Figure 7A-D and Figure 8A-D, $p<0.01$ ). Furthermore, compared with the blank control group, anti-inflammatory cytokine IL-10 was downregulated in the LPS group 
(Figures $7 \mathrm{E}$ and $8 \mathrm{E}, p<0.01$ ). In addition, the treatments groups reduced the expression levels of pro-inflammation cytokines (TNF- $\alpha$, IL-1 $\beta$, IL-6, and IL-8) and increased the expression levels of IL-10 compared with the LPS group (Figure 7A-E and Figure 8A-E, $p<0.01)$
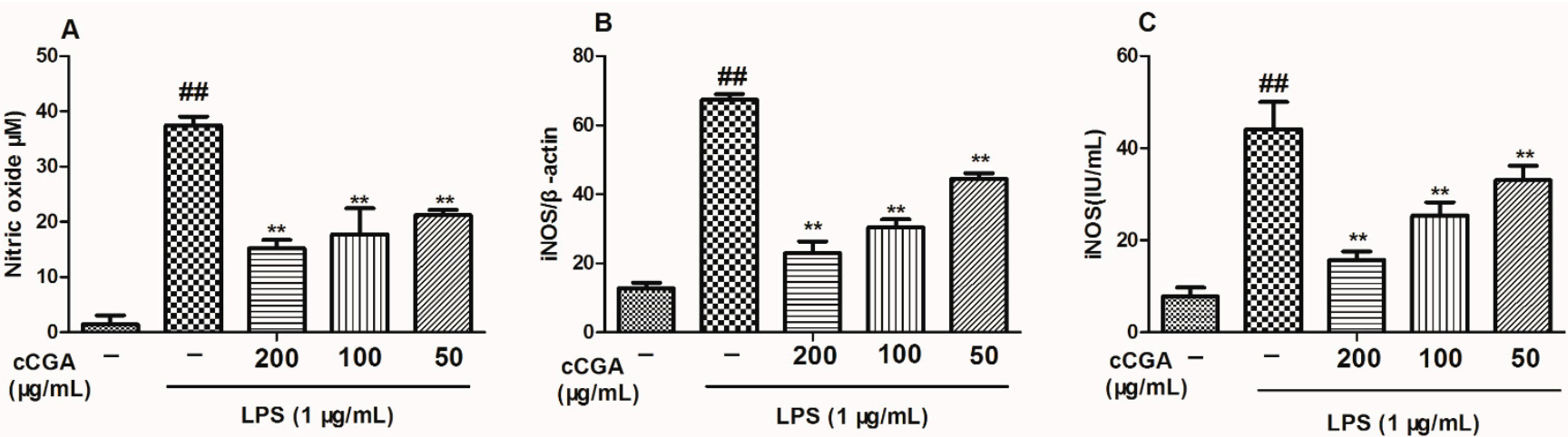

Figure 6. Effects of CCGA from A. adenophora on nitric oxide (NO) and iNOS production in LPSinduced RAW264.7 cells (A) Production level of NO after pretreatment with CCGA at 50-200 $\mu \mathrm{g} / \mathrm{mL}$ for $24 \mathrm{~h}$ and then stimulation by LPS $(1 \mu \mathrm{g} / \mathrm{mL})$ for $16 \mathrm{~h}$. (B) mRNA expression of iNOS after pretreatment with CCGA at $50-200 \mu \mathrm{g} / \mathrm{mL}$ for $24 \mathrm{~h}$ and then stimulation by LPS $(1 \mu \mathrm{g} / \mathrm{mL})$ for $16 \mathrm{~h}$. (C) Protein levels of iNOS after pretreatment with CCGA at 50-200 $\mu \mathrm{g} / \mathrm{mL}$ for $24 \mathrm{~h}$ and then stimulation by LPS $(1 \mu \mathrm{g} / \mathrm{mL})$ for $16 \mathrm{~h}$. Notes: \#\# $p<0.01 \mathrm{vs}$. blank control group, ${ }^{* *} p<0.01 \mathrm{vs}$. LPS, $n=3$ (mean \pm standard deviation).
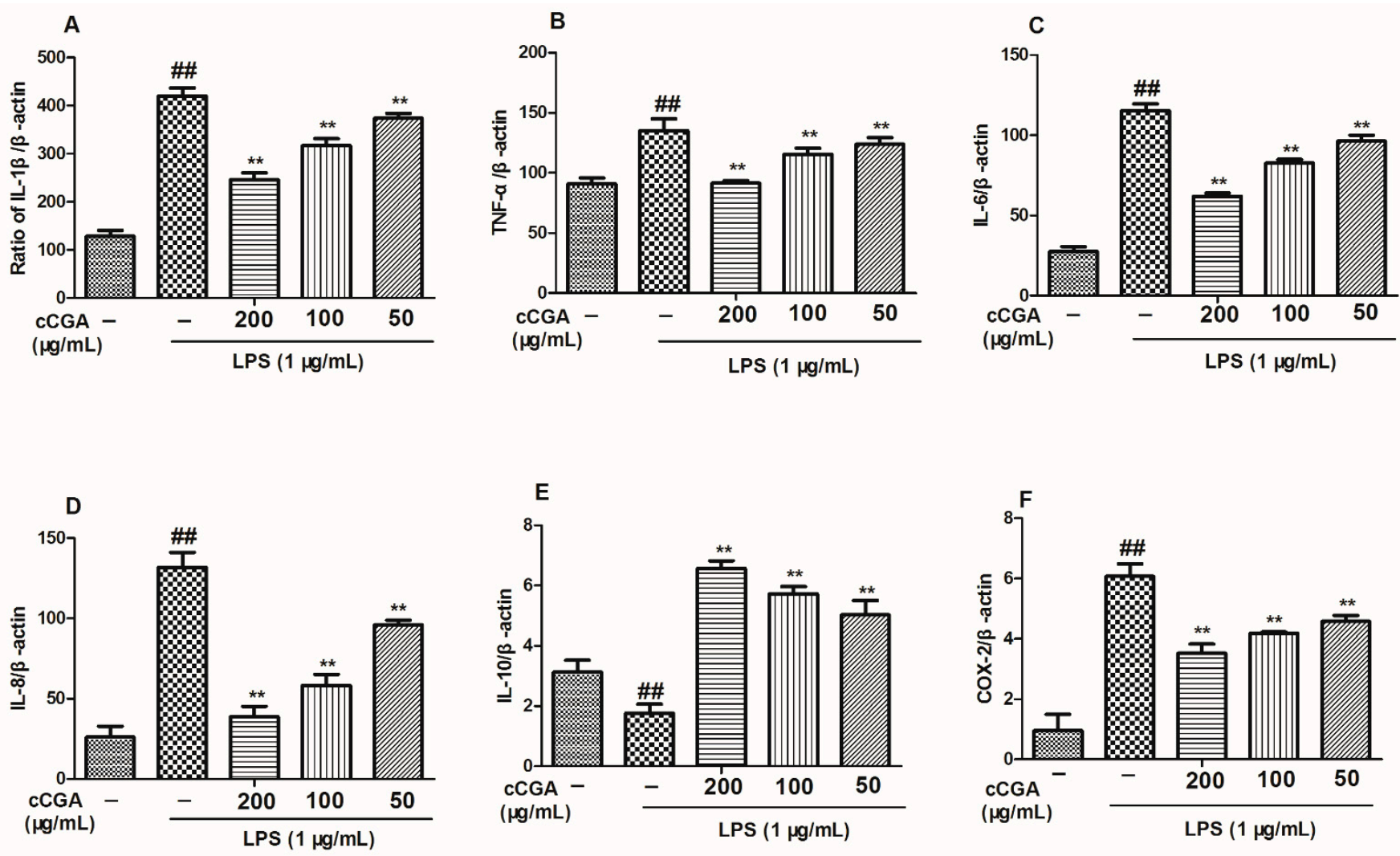

Figure 7. Effects of CCGA from A. adenophora on mRNA level of inflammatory-related cytokines in LPS-induced RAW264.7 cells. (A-E) mRNA level of inflammatory-related cytokines; (F) mRNA level of COX-2. Notes: \#\# $p<0.01$ vs. blank control group, ${ }^{* *} p<0.01$ vs. LPS, $n=3$ (mean \pm standard deviation). 

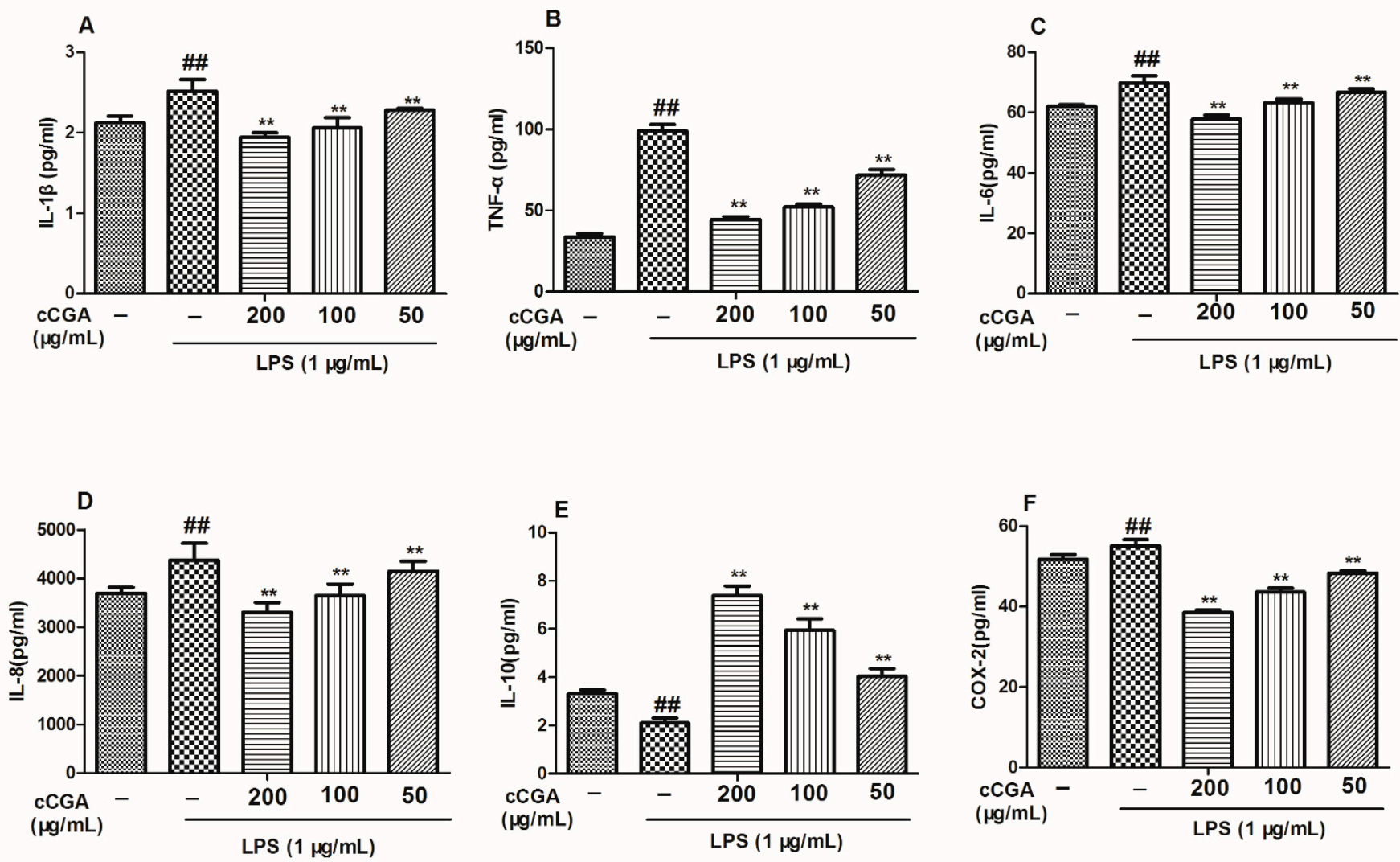

Figure 8. Effects of CCGA from A. adenophora on protein levels of inflammatory-related cytokines and COX-2 in LPS-induced RAW264.7 cells. (A-E) Protein levels of inflammatory-related cytokines. (F) Protein expression of COX-2. Notes: \#\# $p<0.01$ vs. blank control group, ${ }^{* *} p<0.01$ vs. LPS, $n=9$ (mean \pm standard deviation).

\subsection{Effect of CCGA from A. adenophora on COX-2 Expression}

According to the results of this study, the mRNA and protein levels of COX-2 in the LPS group were higher than those in the control blank group (Figures 7F and $8 \mathrm{~F}, p<0.01$ ); however, CCGA could reduce the expression levels of COX-2 compared with the LPS group (Figures $5 \mathrm{~F}$ and $7 \mathrm{~F}, p<0.01$ ).

\subsection{CCGA Inhibited LPS-Induced NF-kB Activation in RAW 264.7 Cells}

To explore the anti-inflammatory mechanism of the CCGA, the NF-kB transcriptional activity was examined by the luciferase reporter gene assay. The results are represented in Figure 9A: CCGA reduced the LPS-induced NF-kB transcriptional activity in RAW 264.7 cells $(p<0.01)$. The main pathway known for the activation of NF-kB involves the phosphorylation of IKK and IKB, which activate the release and translocation of NF-kB into the nucleus. We further explored the cytoplasmic levels of $\mathrm{p}$-IKK, IкB, and p-IкB using Western blot analysis to discover whether CCGA could regulate the NF-kB signaling pathway. We observed that CCGA prevented the phosphorylation of IKK and IKB and the degradation of the IKB protein after LPS stimulation (Figure 9B, $p<0.01$ ). 
A

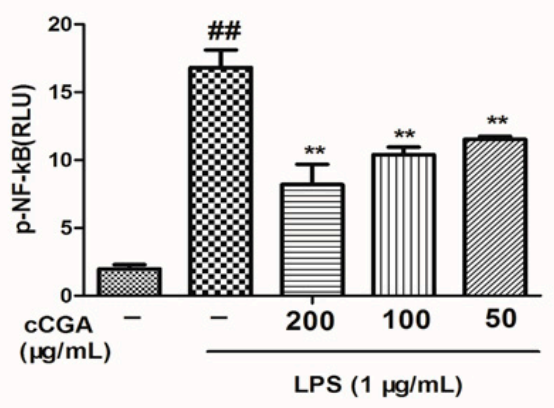

B
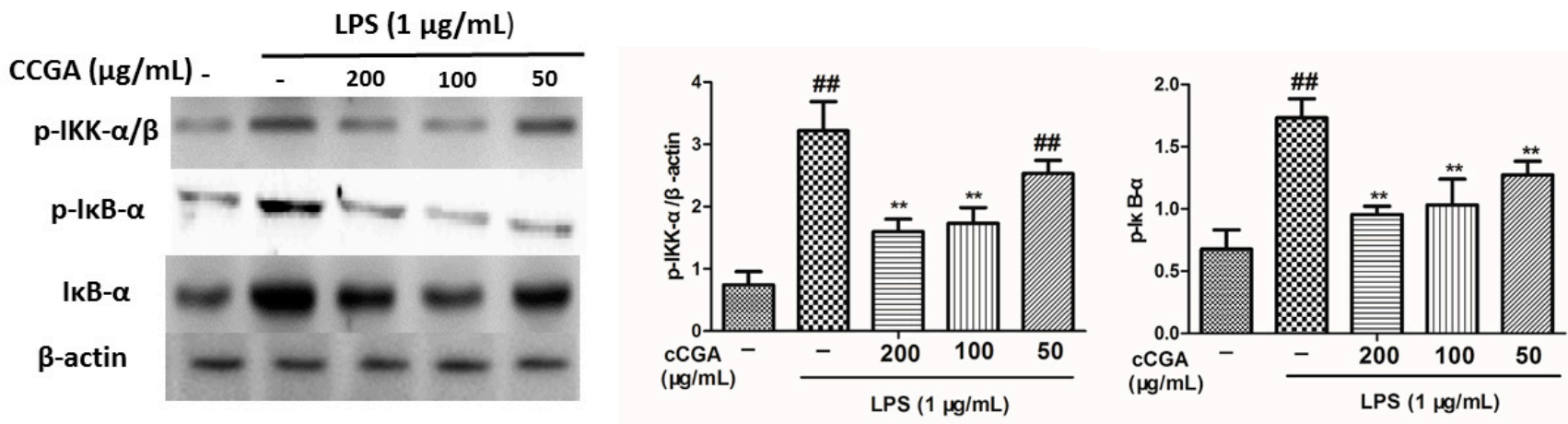

Figure 9. Effect of CCGA isolated from A. adenophora on phosphorylated proteins in NF-kB signaling pathway in LPS-induced RAW264.7 cells. (A) NF-kB transcriptional activity. Values are means \pm standard deviation. (B) Protein levels of IkB- $\alpha$, p-IkB- $\alpha$, and p-IKK in RAW264.7 cells. Notes: \#\# $p<0.01$ vs. blank control group, ${ }^{* *} p<0.01$ vs. LPS, $n=9$ (mean \pm standard deviation).

\section{Discussion}

Plants contain secondary metabolites that are widely used in treating disease conditions [47]. These compounds are known to stimulate biochemical reactions in cells [48]. Pharmacological activities such as anti-aging, antioxidant, anti-cancer, and anti-inflammatory effects have been reported for these plant bioactive compounds [49]. Therefore, this study was conducted to ascertain the anti-inflammatory activity and mechanisms of cryptochlorogenic acid isolated from A. adenophora, an invasive and toxic plant. Our results demonstrate that CCGA at concentrations up to $200 \mu \mathrm{g} / \mathrm{mL}$ has better anti-inflammatory effects with no toxicity to cells; thus, the reduction in pro-inflammatory cytokine production was a result of CCGA activity and not cell death.

LPS activates inflammatory cytokines to terminate iNOS expression, thereby oxidizing L-arginine and increasing the production of $\mathrm{NO}$ [50]. NO, a free oxygen radical, is associated with the pathophysiology of several inflammatory diseases, as they act as cytotoxic agents in cells [51]. In activated macrophages, the production of NO may play a crucial role in the pathology of various acute and chronic inflammatory disorders [50]. Polyphenols decrease the production of NO in LPS induced inflammation. For example, a study by Moore et al. [52] reported that cranberry polyphenol could reduce the levels of NO in LPS-activated RAW 264.7 macrophages. Another study by Bigagli et al. [53] revealed that resveratrol and hydroxytyrosol synergistically inhibited the production of NO and PGE2 in LPS-stimulated RAW 264.7. In our study, we observed that LPS treatment elevated the NO and iNOS levels RAW264.7 cells; however, CCGA treatment could reduce NO production and downregulate the levels of iNOS in LPS-induced RAW264.7 cells. These results were similar to those of a study by Zhao et al. [37], which reported that CCGA at concentrations of 20,40, and $80 \mu \mathrm{M}$ reduced the production of NO and iNOS in LPS-induced RAW264.7 macrophages.

Numerous studies have reported a remarkable increase in pro-inflammatory cytokines in LPS-challenged macrophages and cells $[54,55]$. IL-1 $\beta$, IL-6, and TNF- $\alpha$ are the most 
common cytokines associated with LPS-induced macrophages and have been reported to play vital roles in various biological functions, such as the control of the immune response, homeostasis, and inflammation [56]. In our study, the anti-inflammatory effect of CCGA on the mRNA and protein levels of inflammatory-related cytokines (TNF- $\alpha$, IL-1 $\beta$, IL-6, IL-8, COX-2, and IL-10) in LPS-induced RAW264.7 cells was elucidated. We observed that LPS treatment increased the production of inflammation-related cytokines (TNF- $\alpha$, IL-1 $\beta$, IL-6, IL-8, and COX-2) but reduced the levels of anti-inflammatory cytokine IL-10 in RAW264.7 cells. However, CCGA could prevent the production of these inflammatory cytokines (TNF- $\alpha$, IL-1 $\beta$, IL-6, IL-8, and COX-2) both at the mRNA and protein levels, whereas it enhanced the production of anti-inflammatory cytokines (IL-10) in RAW264.7 cells. These results are consistent with the study by Zhao et al. [37], which reported that the production of pro-inflammatory cytokines (TNF- $\alpha$, IL-6, and COX-2) was reduced after treatment with $150 \mu \mathrm{M}$ CCGA in LPS-induced inflammation in RAW264.7 macrophages. Similarly, Kim et al. [57] also reported that chlorogenic acid could suppress lipopolysaccharide-induced nitric oxide and interleukin- $1 \beta$ expression by hindering JAK2/STAT3 activation in RAW264.7 cells. Therefore, we conclude that CCGA prevented LPS-induced inflammation in RAW264.7 cells by inhibiting the production of inflammationinducing cytokines.

NF- $\kappa \mathrm{B}$ is the key tool for the regulation of pro-inflammatory enzymes and cytokines [58].

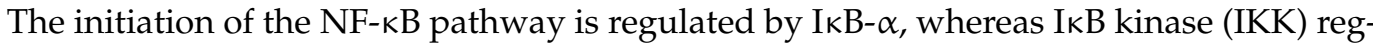
ulates the degradation of IKB- $\alpha$. [59]. Therefore, when IKK phosphorylates, it results in the degradation of I $\kappa$ B $-\alpha$, which then activates NF- $\kappa$ B p65 to stimulate the production of pro-inflammatory factors in the cytoplasm $[60,61]$; hence, the suppression of the NF- $k B$ signaling pathway is a promising strategy for the treatment of inflammatory disorders. Numerous studies have revealed several anti-inflammatory polyphenols that suppress NF- $\mathrm{B}$ signaling [62]. Yang et al. [63] revealed that resveratrol inhibited the initiation of the NF- $\mathrm{B}$ signaling pathway. In addition, another study by Serreli and Deiana [64] also reported that extra virgin olive oil polyphenols could inhibit NF- $\kappa$ B activation, thus reducing the levels of pro-inflammatory factors. Therefore, we investigated the effects of CCGA on the total phosphorylation of NF- $\mathrm{B}$ family proteins (IKK and IKB) in RAW264.7 cells induced by LPS using Western blot. Our results showed that pretreatment with CCGA significantly blocked NF-kB promoter luciferase activity and downregulated the phosphorylation levels of IKK and IкB in LPS-induced RAW264.7 cells in a dose-dependent manner. Similar results were recorded in the study of Li et al. [65]. Therefore, we concluded that CCGA isolated from $A$. adenophora prevented inflammation by inhibiting the phosphorylation of NF- $\mathrm{KB}$ proteins. However, the exact molecular mechanism of the NF- $k B$ signaling pathway inhibition by CCGA is not clear and thus requires further studies.

\section{Conclusions}

In conclusion, CCGA treatment reduced the levels of NO, iNOS, COX-2, and proinflammation cytokines in LPS-induced RAW264.7 cells. The anti-inflammatory properties of CCGA are achieved by blocking or suppressing the NF-kB signaling pathway in RAW 264.7 cells. Therefore, CCGA isolated from Ageratina adenophora can be used as a potential therapeutic agent for the treatment of inflammation-related diseases. However, there is a need for further studies on the exact activity of CCGA in inhibiting the NF- $\mathrm{kB}$ inflammation signaling pathway.

Author Contributions: X.M.: Conceptualization, Methodology, Writing-Original Draft, WritingReview and Editing, Funding Acquisition. S.K.O., Conceptualization, Methodology, WritingOriginal Draft, Writing-Review and Editing. L.H.: Conceptualization, Methodology, WritingOriginal Draft, Software, Validation. J.W.: Methodology, Software, Validation. Z.R.: WritingSoftware, Visualizing, Review, and Editing. J.D.: Writing-Validating, Resources, Review and Editing and supervision, Y.H.: Writing-Review and Editing, Supervision, Funding Acquisition. All authors have read and agreed to the published version of the manuscript. 
Funding: This research was supported by Sichuan Province Science and Technology Support Program (Grant No. 2020YFS0337), School-Enterprise Cooperation Project (grant no. 002-2122339012).

Institutional Review Board Statement: All animal studies were approved by the Institutional Animal Care and Use Committee of Sichuan Agricultural University (certification no. 2019603005). All experiments were conducted in accordance with the Sichuan Agricultural University (SAU) Laboratory Animal Welfare and Ethics guidelines.

Informed Consent Statement: Not applicable.

Data Availability Statement: The data presented in this study are available on request from the corresponding author.

Acknowledgments: We would like to thank Nong Xiang and all the teaching staff at the College of Veterinary Medicine, Sichuan Agricultural University, Chengdu, for their advice and guidance in writing this paper.

Conflicts of Interest: We wish to confirm that there are no known conflict of interest associated with this publication, and there has been no significant financial support for this work that could have influenced its outcome.

\section{References}

1. Mogensen, T.H. Pathogen recognition and inflammatory signaling in innate immune defenses. Clin. Microbiol. Rev. 2009, 22, 240-273. [CrossRef] [PubMed]

2. Serhan, C.N.; Savill, J. Resolution of inflammation: The beginning programs the end. Nat. Immunol. 2005, 6, 1191-1197. [CrossRef]

3. Hotamisligil, G.S. Inflammation, metaflammation and immunometabolic disorders. Nature 2017, 542, 177. [CrossRef] [PubMed]

4. Singh, N.; Baby, D.; Rajguru, J.P.; Patil, P.B.; Thakkannavar, S.S.; Pujari, V.B. Inflammation and cancer. Ann. Afr. Med. 2019, 18, 121-126. [CrossRef]

5. Catrysse, L.G.; van Loo, G. Inflammation and the metabolic syndrome: The tissuespecific functions of NF-kB. Trends Cell Biol. 2017, 27, 417-429. [CrossRef]

6. Eming, S.A.; Krieg, T.; Davidson, J.M. Inflammation in wound repair: Molecular and cellular mechanisms. J. Investig. Dermatol. 2007, 127, 514-525. [CrossRef] [PubMed]

7. Gilbert, D.L. Inflammation in Tic Disorders and Obsessive-Compulsive Disorder: Are PANS and PANDAS a Path Forward? J. Child Neurol. 2019, 34, 598-611. [CrossRef]

8. Kay, J.; Thadhani, E.; Samson, L.; Engelward, B. Inflammation-induced DNA damage, mutations and cancer. DNA Repair 2019, 83, 102673. [CrossRef]

9. Reinehr, T. Inflammatory markers in children and adolescents with type 2 diabetes mellitus. Clin. Chim. Acta 2019, 496, 100-107. [CrossRef]

10. McGeer, E.G.; McGeer, P.L. Inflammatory processes in Alzheimer's disease. Prog. Neuro-Psychopharmacol. Biol. Psychiatry 2003, 27, 741-749. [CrossRef]

11. Fingleton, B. Matrix metalloproteinases as regulators of inflammatory processes. Biochimi. Biophys. (BBA)-Mol. Cell Res. 2017, 1864, 2036-2042. [CrossRef]

12. Reddy, P.; Lent-Schochet, D.; Ramakrishnan, N.; McLaughlin, M.; Jialal, I. Metabolic syndrome is an inflammatory disorder: A conspiracy between adipose tissue and phagocytes. Clin. Chim. Acta 2019, 496, 35-44. [CrossRef]

13. Catarro, M.; Serrano, J.L.; Ramos, S.S.; Silvestre, S.; Almeida, P. Nimesulide analogues: From anti-inflammatory to antitumor agents. Bioorg. Chem. 2019, 88, 102966. [CrossRef] [PubMed]

14. Schumann, R.R.; Pfeil, D.; Lamping, N.; Kirschning, C.; Scherzinger, G.; Schlag, P.; Karawajew, L.; Herrmann, F. Lipopolysaccharide induces the rapid tyrosine phosphorylation of the mitogen-activated protein kinases erk-1 and p38 in cultured human vascular endothelial cells requiring the presence of soluble CD14. Blood 1996, 87, 2805-2814. [CrossRef] [PubMed]

15. Li, T.; Wu, Y.N.; Wang, H.; Ma, J.Y.; Zhai, S.S.; Duan, J. Dapk1 improves inflammation, oxidative stress and autophagy in LPS-induced acute lung injury via p38MAPK/NF-kB signaling pathway. Mol. Immunol. 2020, 120, 13-22. [CrossRef]

16. Mitoma, H.; Horiuchi, T.; Hatta, N.; Tsukamoto, H.; Harashima, S.; Kikuchi, Y.; Otsuka, J.; Okamura, S.; Fujita, S.; Harada, M. Infliximab induces potent anti-inflammatory responses by outside-toinside signals through transmembrane TNF- $\alpha$. Gastroenterology 2005, 128, 376-392. [CrossRef] [PubMed]

17. Liu, X.; Nemeth, D.P.; McKim, D.B.; Zhu, L.; DiSabato, D.J.; Berdysz, O.; Gorantla, G.; Oliver, B.; Witcher, K.G.; Wang, Y.; et al. Cell-Type-Specific Interleukin 1 Receptor 1 Signaling in the Brain Regulates Distinct Neuroimmune Activities. Immunity 2019, 50, 317-333. [CrossRef] [PubMed]

18. Zhu, W.; London, N.R.; Gibson, C.C.; Davis, C.T.; Tong, Z.; Sorensen, L.K.; Shi, D.S.; Guo, J.; Smith, M.C.; Grossmann, A.H.; et al. Interleukin receptor activates a MYD88-ARNO-ARF6 cascade to disrupt vascular stability. Nature 2012, 492, 252-255. [CrossRef]

19. Petersen, A.; Pedersen, B. The role of IL-6 in mediating the anti-inflammatory. J. Physiol. Pharmacol. 2006, 57, 43-51. 
20. Singh, J.K.; Simões, B.M.; Howell, S.J.; Farnie, G.; Clarke, R.B. Recent advances reveal IL-8 signaling as a potential key to targeting breast cancer stem cells. Breast Cancer Res. 2013, 15, 210. [CrossRef]

21. Zhu, X.; Yao, Y.; Yang, J.; Zhengxie, J.; Li, X.; Hu, S.; Zhang, A.; Dong, J.; Zhang, C.; Gan, G. COX-2-PGE2 signaling pathway con-tributes to hippocampal neuronal injury and cognitive impairment in PTZ-kindled epilepsy mice. Int. Immunopharmacol. 2020, 87, 106801. [CrossRef] [PubMed]

22. Lee, A.K.; Sung, S.H.; Kim, Y.C.; Kim, S.G. Inhibition of lipopolysaccharide inducible nitric oxide synthase, TNF-alpha and COX-2 expression by sauchinone effects on I-kappaBalpha phosphorylation, C/EBP and AP-1 activation. Br. J. Pharmacol. 2003, 139, 11-20. [CrossRef]

23. Spiller, F.; Oliveira Formiga, R.; Fernandes da Silva Coimbra, J.; Alves-Filho, J.C.; Cunha, T.M.; Cunha, F.Q. Targeting nitric oxide as a key modulator of sepsis, arthritis and pain. Nitric Oxide 2019, 89, 32-40. [CrossRef]

24. Ally, A.; Powell, I.; Ally, M.M.; Chaitoff, K.; Nauli, S.M. Role of neuronal nitric oxide synthase on cardiovascular functions in physiological and pathophysiological states. Nitric Oxide 2020, 102, 52-73. [CrossRef]

25. Ying, X.; Yu, K.; Chen, X.; Chen, H.; Hong, J.; Cheng, S.; Peng, L. Piperine inhibits LPS induced expression of inflammatory mediators in RAW 264.7 cells. Cell Immunol. 2013, 285, 49-54. [CrossRef]

26. Detmers, P.A.; Hernandez, M.; Mudgett, J.; Hassing, H.; Burton, C.; Mundt, S.; Chun, S.; Fletcher, D.; Card, D.J.; Lisnock, J.; et al Deficiency in inducible nitric oxide synthase results in reduced atherosclerosis in apolipoprotein E-deficient mic. J. Immunol. 2000, 16, 3430-3435. [CrossRef] [PubMed]

27. Korhonen, R.; Lahti, A.; Kankaanranta, H.; Moilanen, E. Nitric oxide production and signaling in inflammation. Curr. Drug Targets Inflamm. Allergy 2005, 4, 471-479. [CrossRef]

28. Murtas, D.; Piras, F.; Minerba, L.; Ugalde, J.; Piga, M.; Maxia, C.; Perra, M.T.; Sirigu, P. Nuclear factor- $\kappa B$ expression is predictive of overall survival in patients with cutaneous melanoma. Oncol. Lett. 2010, 1, 633-639. [CrossRef] [PubMed]

29. Liu, H.; Talalay, P. Relevance of anti-inflammatory and antioxidant activities of exemestane and synergism with sulforaphane for disease prevention. Proc. Natl. Acad. Sci. USA 2013, 110, 19065-19070. [CrossRef] [PubMed]

30. Babu, P.V.; Liu, D.; Gilbert, E.R. Recent advances in understanding the anti-diabetic actions of dietary flavonoids. J. Nutr. Biochem. 2013, 24, 1777-1789. [CrossRef]

31. Kumar, N.; Goel, N. Phenolic acids: Natural versatile molecules with promising therapeutic applications. Biotechnol. Rep. 2019, 24, e00370. [CrossRef] [PubMed]

32. Sato, Y.; Itagaki, S.; Kurokawa, T.; Ogura, J.; Kobayashi, M.; Hirano, T.; Iseki, K. In vitro and in vivo antioxidant properties of chlorogenic acid and caffeic acid. Int. J. Pharm. 2011, 403, 136-138. [CrossRef]

33. Lou, Z.; Wang, H.; Zhu, S.; Ma, C.; Wang, Z. Antibacterial activity and mechanism of action of chlorogenic acid. J. Food Sci. 2011, 76, M398-M403. [CrossRef]

34. Dos Santos, M.D.; Almeida, M.C.; Lopes, N.P.; De Souza, G.E.P. Evaluation of the antiinflammatory, analgesic and antipyretic activities of the natural polyphenol chlorogenic acid. Biol. Pharm. Bull. 2006, 29, 2236-2240. [CrossRef]

35. Barahuie, F.; Hussein, M.Z.; Arulselvan, P.; Fakurazi, S.; Zainal, Z. Controlled in vitro release of the anticancer drug chlorogenic acid using magnesium/aluminiumlayered double hydroxide as a nanomatrix. Sci. Adv. Mater. 2016, 8, 501-513. [CrossRef]

36. Hwang, S.J.; Kim, Y.W.; Park, Y.; Lee, H.J.; Kim, K.W. Anti-inflammatory effects of chlorogenic acid in lipopolysaccharidestimulated raw 264.7 cells. Inflamm. Res. 2014, 63, 81-90. [CrossRef]

37. Zhao, X.L.; Yu, L.; Zhang, S.D.; Ping, K.; Ni, H.Y.; Qin, X.Y.; Zhao, C.J.; Wang, W.; Efferth, T.; Fu, Y.J. Cryptochlorogenic acid attenu-ates LPS-induced inflam;matory response and oxidative stress via upregulation of the Nrf2/HO-1 signaling pathway in RAW 264.7 macrophages. Int. Immunopharmacol. 2020, 83, 106436. [CrossRef]

38. Ouyang, C.; Liu, X.; Yan, D.; Li, Y.; Wang, Q.; Cao, A.; Guo, M. Immunotoxicity assessment of cadinene sesquiterpenes from Eupatorium adenophorum in mice. J. Integr. Agric. 2016, 15, 2319-2325. [CrossRef]

39. Okyere, S.K.; Wen, J.; Cui, Y.; Xie, L.; Gao, P.; Wang, J.; Wang, S.; Hu, Y. Toxic mechanisms and pharmacological properties of euptox A, a toxic monomer from A. adenophora. Fitoterapia 2021, 155, 105032. [CrossRef]

40. Ren, Z.; Gao, P.; Okyere, S.K.; Cui, Y.; Wen, J.; Jing, B.; Deng, J.; Hu, Y. Ageratina adenophora inhibits spleen immune function in rats via the loss of the FRC Network and Th1-Th2 Cell Ratio elevation. Toxins 2021, 13, 309. [CrossRef] [PubMed]

41. Cui, Y.; Okyere, S.K.; Gao, P.; Wen, J.; Cao, S.; Wang, Y.; Deng, J.; Hu, Y. Ageratina adenophora Disrupts the Intestinal Structure and Immune Barrier Integrity in Rats. Toxins 2021, 13, 651. [CrossRef]

42. Okyere, S.K.; Mo, Q.; Pei, G.; Ren, Z.; Deng, J.; Hu, Y. Euptox A induces G0/G1 arrest and apoptosis of hepatocyte via ROS, mitochondrial dysfunction and caspases-dependent path- ways in vivo. J. Toxicol. Sci. 2020, 45, 661-671. [CrossRef]

43. Ren, Z.; Okyere, S.K.; Wen, J.; Xie, L.; Cui, Y.; Wang, S.; Wang, J.; Cao, S.; Shen, L.; Ma, X.; et al. An Overview: The Toxicity of Ageratina adenophora on Animals and Its Possible Interventions. Int. J. Mol. Sci. 2021, 22, 11581. [CrossRef] [PubMed]

44. Okyere, S.K.; Wen, J.; Cui, Y.; Xie, L.; Gao, P.; Zhang, M.; Wang, J.; Wang, S.; Ran, Y.; Ren, Z.; et al. Bacillus toyonensis SAU-19 and SAU-20 isolated from Ageratina adenophora alleviates the intestinal structure and integrity damage associated with gut dysbiosis in mice fed high fat mice. Front. Microbiol. 2021; in press. [CrossRef]

45. Okyere, S.K.; Xie, L.; Wen, J.; Ran, Y.; Ren, Z.; Deng, J.; Hu, Y. Bacillus toyonensis SAU-19 Ameliorates Hepatic Insulin Resistance in High-Fat Diet/Streptozocin-Induced Diabetic Mice. Nutrients 2021, 13, 4512. [CrossRef] [PubMed]

46. Poudel, R.; Neupane, N.P.; Mukeri, I.H.; Alok, S.; Verma, A. An updated review on invasive nature, phytochemical evaluation, \& pharmacological activity of Ageratina adenophora. Int. J. Pharm. Sci. Res. 2020, 119, 2510-2520. 
47. Parthasarathy, M.; Evan Prince, S. The potential effect of phytochemicals and herbal plant remedies for treating drug-induced hepatotoxicity: A review. Mol. Biol. Rep. 2021, 48, 4767-4788. [CrossRef]

48. Forni, C.; Facchiano, F.; Bartoli, M.; Pieretti, S.; Facchiano, A.; D’ Arcangelo, D.; Norelli, S.; Valle, G.; Nisini, R.; Beninati, S.; et al Beneficial Role of Phytochemicals on Oxidative Stress and Age-Related Diseases. Biomed. Res. Int. 2019, 2019, 8748253. [CrossRef]

49. George, B.P.; Chandran, R.; Abrahamse, H. Role of Phytochemicals in Cancer Chemoprevention: Insights. Antioxidants 2021, 10, 1455. [CrossRef]

50. Aktan, F. iNOS-mediated nitric oxide production and its regulation. Life Sci. 2004, 75, 639-653. [CrossRef]

51. Cirino, G.; Distrutti, E.; Wallace, J.L. Nitric oxide and inflammation. Inflamm. Allergy Drug Targets 2006, 5, 115-119. [CrossRef] [PubMed]

52. Moore, K.; Howard, L.; Brownmiller, C.; Gu, I.; Lee, S.O.; Mauromoustakos, A. Inhibitory effects of cranberry polyphenol and volatile extracts on nitric oxide production in LPS activated RAW 264.7 macrophages. Food Funct. 2019, 10, 7091-7102. [CrossRef] [PubMed]

53. Bigagli, E.; Cinci, L.; Paccosi, S.; Parenti, A.; D'Ambrosio, M.; Luceri., C. Nutritionally relevant concentrations of resveratrol and hydroxytyrosol mitigate oxidative burst of human granulocytes and monocytes and the production of pro-inflammatory mediators in LPS-stimulated RAW 264.7 macrophages. Int. Immunopharmacol. 2017, 43, 147-155. [CrossRef]

54. Hung, Y.-L.; Miyazaki, H.; Fang, S.-H.; Li, C.-Y.; Suzuki, K. The Structural Characteristics of Green Tea Polyphenols on Lipopolysaccharide-Stimulated RAW Cells. J. Nutr. Biol. 2018, 2, 151-157. [CrossRef]

55. Li, C.-Y.; Suzuki, K.; Hung, Y.-L.; Yang, M.-S.; Yu, C.-P.; Lin, S.-P.; Hou, Y.-C.; Fang, S.-H. Aloe metabolites prevent LPS-induced sepsis and inflammatory response by inhibiting mitogen-activated protein kinase activation. Am. J. Chin. Med. 2017, 45, 847-861. [CrossRef] [PubMed]

56. Yeom, M.; Kim, J.H.; Min, J.H.; Hwang, M.K.; Jung, H.S.; Sohn, Y. Xanthii fructus inhibits inflammatory responses in LPSstimulated RAW 264.7 macrophages through suppressing NF-кB and JNK/p38 MAPK. J. Ethnopharmacol. 2015, 176, 394-401. [CrossRef]

57. Kim, S.H.; Park, S.Y.; Park, Y.L.; Myung, D.S.; Rew, J.S.; Joo, Y.E. Chlorogenic acid suppresses lipopolysaccharide-induced nitric oxide and interleukin-1 $\beta$ expression by inhibiting JAK2/STAT3 activation in RAW264.7 cells. Mol. Med. Rep. 2017, 16, 9224-9232. [CrossRef]

58. Kunnumakkara, A.B.; Shabnam, B.; Girisa, S.; Harsha, C.; Banik, K.; Devi, T.B.; Choudhury, R.; Sahu, H.; Parama, D.; Sailo, B.L.; et al. Inflammation, NF-кB, and Chronic Diseases: How are They Linked? Crit. Rev. Immunol. 2020, 40, 1-39. [CrossRef] [PubMed]

59. Endale, M.; Park, S.C.; Kim, S.; Kim, S.H.; Yang, Y.; Cho, J.Y.; Rhee, M.H. Quercetin disrupts tyrosine-phosphorylated phosphatidylinositol 3-kinase and myeloid differentiation factor-88 association, and inhibits MAPK/AP-1 and IKK/NF-KB-induced inflammatory mediators production in RAW 264.7 cells. Immunobiology 2013, 218, 1452-1467. [CrossRef]

60. Cheng, S.C.; Huang, W.C.; Pang, J.H.; Wu, Y.H.; Cheng, C.Y. Quercetin Inhibits the Production of IL-1 $\beta$-Induced Inflammatory Cytokines and Chemokines in ARPE-19 Cells via the MAPK and NF-кB Signaling Pathways. Int. J. Mol. Sci. 2019, $20,2957$. [CrossRef] [PubMed]

61. Pontoriero, M.; Fiume, G.; Vecchio, E.; de Laurentiis, A.; Albano, F.; Iaccino, E.; Mimmi, S.; Pisano, A.; Agosti, V.; Giovannone, E.; et al. Activation of NF- $\mathrm{kB}$ in B cell receptor signaling through Bruton's tyrosine kinase-dependent phosphorylation of IkB- $\alpha$. J. Mol. Med. 2019, 97, 675-690. [CrossRef] [PubMed]

62. Yahfoufi, N.; Alsadi, N.; Jambi, M.; Matar, C. The Immunomodulatory and Anti-Inflammatory Role of Polyphenols. Nutrients 2018, 10, 1618. [CrossRef] [PubMed]

63. Yang, X.; Xu, S.; Qian, Y.; Xiao, Q. Resveratrol regulates microglia M1/M2 polarization via PGC-1 $\alpha$ in conditions of neuroinflammatory injury. Brain Behav. Immun. 2017, 64, 162-172. [CrossRef] [PubMed]

64. Serreli, G.; Deiana, M. Extra Virgin Olive Oil Polyphenols: Modulation of Cellular Pathways Related to Oxidant Species and Inflammation in Aging. Cells 2020, 9, 478. [CrossRef]

65. Li, Q.; Sun, J.; Mohammadtursun, N.; Wu, J.; Dong, J.; Li, L. Curcumin inhibits cigarette smoke-induced inflammation via modulating the PPAR $\gamma-\mathrm{NF}-\mathrm{kB}$ signaling pathway. Food Funct. 2019, 10, 7983-7994. [CrossRef] 